\title{
Commentary: Inspiration and cultivation-Students to cardiothoracic surgeons
}

\author{
David G. Lehenbauer, MD, and Dawn S. Hui, MD
}

\footnotetext{
From the Department of Cardiothoracic Surgery, University of Texas Health Science Center at San Antonio, San Antonio, Tex.

Disclosures: Authors have nothing to disclose with regard to commercial support

Received for publication Aug 5, 2019; accepted for publication Aug 6, 2019; available ahead of print Oct 18 , 2019.

Address for reprints: Dawn S. Hui, MD, 7703 Floyd Curl Dr, Suite 211L, San Antonio, TX 78229 (E-mail: huid@ uthscsa.edu).

J Thorac Cardiovasc Surg 2020;159:1915-6

$0022-5223 / \$ 36.00$

Copyright (c) 2019 by The American Association for Thoracic Surgery

https://doi.org/10.1016/j.jtcvs.2019.08.056
}

The sky is falling. There are fewer trainees in surgery residency programs, more examination failures, fewer American Board of Thoracic Surgery certifications, an aging population, and looming retirement for a significant portion of the workforce. These factors have been cited in the impending cardiothoracic surgeon shortage. ${ }^{1,2}$ Our field and our patients are in dire need of an ample supply of exceptionally talented students choosing a career and a life in cardiothoracic surgery (CTS). Many students today desire a career that will afford them the opportunity to pursue and develop interests outside work. The time and passion needed to become a competent cardiothoracic surgeon, however, is frequently in juxtaposition with meaningful work-life balance. Undeniably, the cost of becoming a cardiothoracic surgeon is high.

In this issue of the Journal, Coyan and colleagues ${ }^{3}$ shed light on medical student perceptions of and interest in CTS. They conducted an anonymous survey of medical students at their institution, on a voluntary basis and without offering compensation; not surprisingly, the response rate was $22 \%$. Generally held positive attitudes included the intellectual challenge, direct patient impact, and leadership of health care teams. Some readers may be surprised at other positive attitudes, such as the view that CTS is a growing and thriving field, or that surgeons are adequately compensated for their efforts. The former highlights the success of our field in staying engaged and on the forefront of technologic health care innovations; the latter may reflect shifting supply-demand curves. Work-life balance was cited by $82 \%$ as a deterrent, however, and Coyan and colleagues ${ }^{3}$ found it to be the most likely reason for attrition of interest between years 1 and 2 (from $30 \%$ to $6 \%$ ) and years 3 and 4 (from $15 \%$ to $6 \%$ ).

Interestingly, sacrificing work-life balance for career is a traditional expectation in nonmedical fields, including technology start-ups, entrepreneurship, and investment banking. ${ }^{4-6}$ These fields seem to have little trouble recruiting young candidates, although consultants have

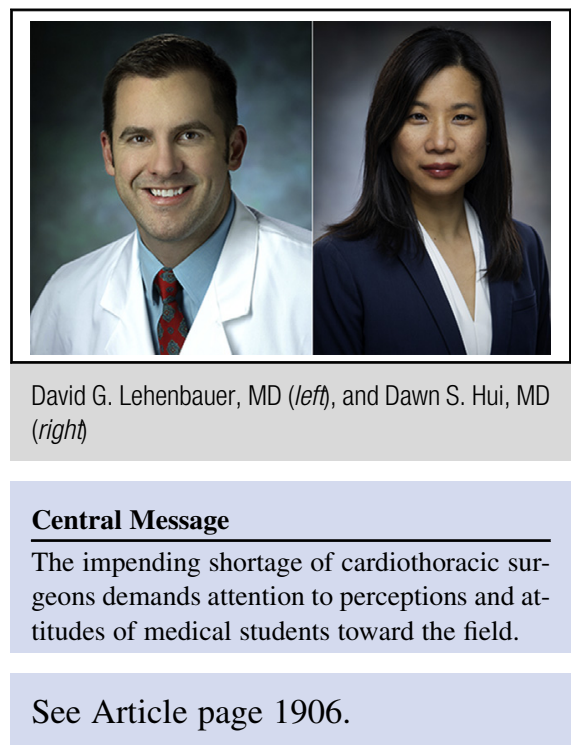

recently noted similar generational rifts, with the responsibility of balance being placed on the employer or business owner. ${ }^{5,7}$ Notable differences in CTS include a longer training pipeline, smaller candidate pool, more complex and less nimble workplace structures, and a lower ceiling on eventual personal and financial independence. Being a cardiothoracic surgeon is a life's calling, not merely a career. Total commitment to patients and requirement for the surgeon's complete physical and mental presence are immutable, or at most only partially modifiable, factors.

Our efforts thus should focus on influencing students' calculus of cost and reward. From the results of Coyan and colleagues, ${ }^{3}$ students are astute enough to appreciate the latter. One intriguing question is how students are primed to evaluate the former. Do colleagues and advisors from other disciplines dissuade students early on, on the basis of their own opinions and biases? What is our responsibility in transforming the perceptions of our field at our own institutions? When we talk about difficult cases, what is the subtext that students read? Is it the surgeon's personal time, effort, and cost, or the rewarding aspects of changing the outcome? In the age of social media, new avenues exist to engage more broadly and shape the perceptions of our field. One example is the Thoracic Surgery Social Media Network. Another Journal innovation is the Young Surgeons' page, a "unique and fresh view of our profession... that will allow a more complete understanding of all facets of our specialty." ${ }^{8}$ These should, however, supplement and 
not replace the positive mentorship and exposure experiences recommended by Coyan and colleagues. ${ }^{3}$ Individual mentorship requires significant efforts, within the confines of time and reachability, but ultimately there may be no better way to cultivate the future leaders of cardiothoracic surgery. Broadening these views and conversations with medical students may hold the key to our specialty's future. Although it remains to be seen whether these efforts will provide the meaningful inspiration to compel the best and brightest to pursue cardiothoracic surgery, we are optimistic that these future-oriented endeavors will keep the sky held high.

\section{References}

1. Grover A, Gorman K, Dall TM, Jonas R, Lytle B, Shemin R, et al. Shortage of cardiothoracic surgeons is likely by 2020. Circulation. 2009;120:488-94.
2. Moffatt-Bruce S, Crestanello J, Way DP, Williams TE Jr. Providing cardiothoracic services in 2035: signs of trouble ahead. J Thorac Cardiovasc Surg. 2018;155: 824-9.

3. Coyan GN, Kilic A, Gleason TG, Schuchert MJ, Luketich JD, Okusanya O, et al. Medical student perceptions of a career in cardiothoracic surgery: results of an institutional survey. J Thorac Cardiovasc Surg. 2020;159:1906-12.

4. Tiku N. The gospel of hard work, according to Silicon Valley. Wired. Available at: https://www.wired.com/2017/06/silicon-valley-still-doesnt-care-work-life-balance/. Accessed August 5, 2019.

5. Cook J. Is work-life balance overrated? Forbes. Available at: https://www.forbes. com/sites/jodiecook/2019/08/01/work-life-balance/\#3b099e7964af. Accessed August $5,2019$.

6. Sanghoee S. Why banking and work-life balance don't mix. Fortune. Available at: https://fortune.com/2014/02/04/why-banking-and-work-life-balance-dont-mix/. Accessed August 5, 2019

7. Conerly B. Hiring young workers who want work-life balance: what's an employer to do? Forbes. Available at: https://www.forbes.com/sites/billconerly/2019/01/12/ hiring-young-workers-who-want-work-life-balance-whats-an-employer-to-do/ \#12804ce0e4e4. Accessed August 5, 2019.

8. Vaporciyan AA, Yang SC, Fann JI. The young surgeons' page. J Thorac Cardiovasc Surg. 2019;157:669-70. 